\section{Andrzej T. Kubanowski}

Uniwersytet Mikołaja Kopernika, Toruń

a.kubanowski@gmail.com

DOI: http://dx.doi.org/10.12775/BPTh.2016.031

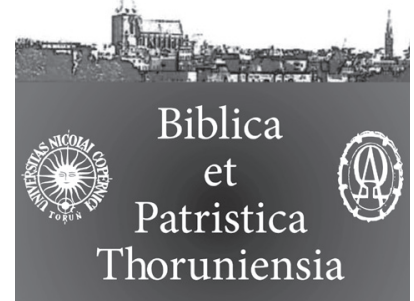

9 (2016) 3: 223-226

ISSN (print) 1689-5150

ISSN (online) 2450-7059

\title{
P. Roszak, J. Vijgen (red.), Reading Sacred Scripture with Thomas Aquinas. Hermeneutical Tools, Theological Questions and New Perspectives, Brepols Publishers, Turnhout 2015, ss. 601(16)
}

$\int \mathrm{r}$ ak wynika już z samego tytułu, niniejsza książka stanowi zbiór esejów, w których poszczególni autorzy podejmują się scharakteryzowania i wprowadzenia w tematykę biblijnych komentarzy św. Tomasza z Akwinu, skupiając się zasadniczo na refleksjach dotyczących narzędzi hermeneutycznych stosowanych przez Akwinatę, pojawiających się na tej kanwie pytań o ich teologiczne znaczenie oraz nowych perspektyw dla dalszych badań.

Publikacja ukazała się w ramach serii Féderation Internationale des Instituts d'Études Médiévales, Textes et Études du Moyen Âge, 80 i została podzielona na dwie części. W pierwszej części redaktorzy umieścili eseje opisujące narzędzia hermeneutyczne stosowane przez Tomasza z Akwinu oraz refleksje dotyczące pewnych aspektów jego hermeneutyki biblijnej. W części drugiej znajdują się natomiast artykuły poruszające konkretne kwestie teologiczne i kreślące nowe perspektywy dla dalszych badań w kontekście biblijnych komentarzy Akwinaty. Łącznie książka składa się z 19 prac. Redaktorzy opatrzyli ją także wstępem zatytułowanym Towards a 'Biblical Thomism': Introduction (s. VII-XVI) oraz zbiorem bibliografii (s. 555-590) i indeksów (s. 591-601).

We wstępie przedstawiony jest zarys komentatorskiej praktyki Tomasza z Akwinu, w którym podkreślone zostały podstawowe założenia stosowanej przez niego hermeneutyki biblijnej, ich pochodzenie, wcześniejsze wpływy oraz struktura. Warte zwrócenia uwagi jest również zdanie redaktorów uwydatniające znaczenie egzegezy Pisma Świętego dla całości myśli Akwinaty przekazywanej też w jego dziełach systematycznych. Ta idea zawiera się także w celu niniejszego zbioru, którym jest wprowadzenie do teologicznych rozważań nad biblijnymi komentarzami św. Tomasza systematycznej refleksji służącej rozwinięciu ich hermeneutycznej perspektywy oraz dania przyczynku przyszłym badaniom. Przez realizację owego celu następuje przybliżenie i ukazanie współczesnym czytelnikom, w jaki sposób teologiczna spuścizna 
Doktora Anielskiego mogła stanowić formę spekulatywnej lektury objawionego Słowa Bożego, poddanej regułom konkretnej dydaktyki. Stąd kolejne eseje w książce zostały przygotowane przez specjalistów z zakresu różnych dziedzin nauk humanistycznych, aby razem współtworzyć komplementarną odpowiedź na postawione we wprowadzeniu zadanie.

Po wstępie następuje część I: Hermeneutical Tools, w której umieszczone zostały artykuły takich autorów jak: Marco Passarotti, Gilbert Dahan, Elisabeth Reinhardt, Jeremy Holmes, Piotr Roszak, Mauricio Narváez, Margherita Maria Rossi, Olivier-Thomas Venard, Timothy F. Bellamah, Leo Elders, Jörgen Vijgen. Badacze podejmują w niej zakres tematów od tworzenia banku drzew w ramach Index Thomisticus, co przynależy do dziedziny lingwistyki i badań syntaktycznych, po funkcję używania przez Akwinatę w komentarzach biblijnych odniesień do Arystotelesa, czyli zagadnienia z obszaru filozofii. Wszystkie eseje w ramach I części publikacji są godne lektury i własnego rozważenia poruszanej w nich tematyki. Należy więc wspomnieć choćby tylko kilka z nich, m.in. pracę G. Dahan pt. Thomas Aquinas Exegesis and Hermeneutics (s. 45-70), w której ten znany francuski uczonyw sposób syntetyczny, a jednocześnie komplementarny przedstawia problematykę rozumienia oraz odczytywania przez Akwinatę poszczególnych sensów biblijnych. Stosowne nakreślenie owego zagadnienia jest kluczowym elementem dla prowadzenia właściwej refleksji teologicznej opierającej się na średniowiecznych dziełach egzegetycznych św. Tomasza z Akwinu. W artykule Participation and the Meaning of Scripture (s. 91-113), J. Holmes prezentuje, w jaki sposób filozoficzna teoria partycypacji miała wpływ nie tylko na postrzeganie przez Akwinatę rzeczywistości, lecz również na sposób rozumienia przez niego orędzia Pisma Świętego, szczególnie w ramach sensu duchowego. Z innej perspektywy ten istotny temat analizuje O.T. Venard, który swoim esejem Metaphor in Aquinas: Between Necessitas and Delectatio (s. 199-228), nakreśla zarówno podstawy metodologicznego wykorzystywania metafory przez Doktora Anielskiego, jak też znaczenia owej korelacji kształtującej się pomiędzy literalnym rozumieniem a językiem teologicznym odsłaniającym swoiste misterium Słowa Bożego. Na zakończenie części I J. Vijgen artykułem pt. Aristotle in Aquinas's Biblical Commentaries (s. 288-346) wyjaśnia i zarysowuje kontekst, w którym św. Tomasz w swoich komentarzach biblijnych odnosił się bezpośrednio do myśli filozoficznej Stagiryty. Na końcu tego artykułu autor umieścił bardzo użyteczny apendyks (s. 338-346) z listą miejsc w komentarzach do poszczególnych ksiąg Pisma Świętego, w których znajdują się odniesienia do dzieł Arystotelesa.

Odnosząc się do całości materiałów zawartych w części Hermeneutical Tools, można poczynić dwie uwagi. Pierwsza, tak bogaty zbiór treści dotyczących hermeneutyki biblijnej stosowanej przez Tomasza z Akwinu należałoby 
uzupełnić jeszcze o artykuł, który nawet w sposób syntetyczny podejmowałby kwestię omówienie elementów struktury samych komentarzy biblijnych, takich jak np. prolog. Druga, na oddzielny esej zasługiwałby również temat autorytetów oraz całej idei wykorzystywania ich przez Akwinatę w swoich komentarzach. Owa tematyka jest częściowo zawarta między innymi w artykułach P. Roszaka oraz L. Eldersa, lecz przez swoją ważność dla kształtowania całej średniowiecznej egzegezy biblijnej powinna stać się przedmiotem odrębnej i szczegółowej refleksji.

Druga część książki zatytułowana została Theological Questions and New Perspective, a eseje do niej przygotowali następujący autorzy: Matthew Levering, Enrique Martínez, Robert J. Woźniak, Mirosław Mróz, Lluís Clavell, Matthew Ramage, Daniel Keating, Christopher Baglow. Wśród nich znajdują się światowej klasy specjaliści i badacze, którzy swoimi publikacjami sami wyznaczają kierunki rozwoju refleksji nad biblijnymi komentarzami św. Tomasza z Akwinu. Tak samo jak w poprzedniej, również umieszczone w tej części artykuły są bardzo interesujące, stąd zasługują na wnikliwą lekturę oraz osobiste rozważenie przedstawianej w nich tematyki. Problematyka poruszanych zagadnień jest na tyle szeroka i wieloaspektowa, że trudno ją streści w kilku szczegółowych stwierdzeniach. Ogólnie ujmując, niniejsi autorzy swoimi esejami prezentują zróżnicowane ścieżki refleksji oparte na biblijnej hermeneutyce Akwinaty oraz jej znaczenie dla lepszego rozumienia i rozwoju współczesnych zagadnień związanych z moralnością, teologią systematyczną, duszpasterstwem, a także współczesnym odczytywaniem Pisma Świętego.

Książka Reading Sacred Scripture with Thomas Aquinas swoją treścią rozszerza perspektywę badawczą i uzupełnia w swoisty sposób refleksje znajdujące się w publikacji pod redakcją Daniela A. Keatinga, Thomasa G. Weinandy i Johna P. Yocuma, wydanej w 2005 roku$^{1}$. Zbiera również i systematyzuje zagadnienia pojawiające się we wcześniejszych tytułach redagowanych m.in. przez M. Leveringa ${ }^{2}$. Publikacja pod redakcją P. Roszaka i J. Vijgena jest zbiorem zróżnicowanych podejść do różnych zagadnień, których jednak wspólną cechą jest oparcie się w perspektywie biblijnej hermeneutyki stosowanej przez Akwinatę na komentarzach do Pisma Świętego. Pomimo drobnych pominięć

1 D. Keating, T. Weinandy, J. Yocum (red.), Aquinas on Scripture. An Introduction to His Biblical Commentaries, ss. 257(12).

2 M. Dauphinais, M. Levering (red.), Reading John with St. Thomas Aquinas. Theological Exegesis and Speculative Theology, ss. 398; iidem, Reading Romans with St. Thomas Aquinas, ss. 336; M. Levering, Scripture and Metaphysics. Aquinas and the Renewal of Trinitarian Theology, ss. 254(10); idem, Participatory Biblical Exegesis: A Theology of Biblical Interpretation, ss. 344; 
w zakresie poszczególnych narzędzi hermeneutycznych pozycja ta posiada komplementarny charakter. Badacze z różnych dziedzin teologii, filozofii oraz innych nauk humanistycznych pośród artykułów w niej zamieszonych znajdą fachowo i interesująco przedstawione zagadnienia pozostające $\mathrm{w}$ orbicie odniesień do spuścizny Tomasza z Akwinu. Natomiast dla naukowców oraz specjalistów, którzy obecnie lub w niedalekiej przyszłości pragną zajmować się analizą dzieł egzegetycznych Akwinaty, albo szerzej rozumianą refleksją w ramach tzw. tomizmu biblijnego, jest to pozycja do obowiązkowej lektury.

\section{Bibliografia}

Keating, D., Weinandy, T., Yocum, J. (red.), Aquinas on Scripture. An Introduction to His Biblical Commentaries, T\&T Clark, London-New York 2005.

Dauphinais, M., Levering, M. (red.), Reading John with St. Thomas Aquinas. Theological Exegesis and Speculative Theology, The Catholic University of America Press, Washington D.C. 2005.

Dauphinais, M., Levering, M., Reading Romans with St. Thomas Aquinas, The Catholic University of America Press, Washington D.C. 2012.

Levering, M., Scripture and Metaphysics. Aquinas and the Renewal of Trinitarian Theology, Blackwell Publishing, Malden 2004.

Levering, M., Participatory Biblical Exegesis: A Theology of Biblical Interpretation, Notre Dame Press, Notre Dame 2008. 